\title{
DEMOCRATIC LEGITIMACY AS A CRITERION FOR RECOGNIZING A GOVERNMENT: TOWARDS THE EMERGENCE OF A REGIONAL CUSTOMARY RULE IN THE AMERICAS? A REPLY TO PROFESSOR ERIKA DE WET
}

\author{
Vasiliki Saranti*
}

\section{Introductory Remarks}

As Erika de Wet argues ${ }^{1}$ in this symposium, the effective protection of democracy in the domestic legal order was neither a priority, nor even a matter of concern for the international community when the United Nations was established. Similarly, the legality of a regime at the international level was not an object of study for international law. A governmental structure that was exercising effective control of a state, irrespective of the means it used to seize power, would enjoy legal standing in international fora. Likewise, the democratic legitimacy of the government was not a prerequisite for the recognition of a state, nor was it a condition for participation in an international organization, whether of universal (UN) or regional character (European Community, Organization of African Unity). The Pact of the League of Arab States ${ }^{2}$ went even further by imposing an obligation to recognize a state and hence its government, whether or not it was legitimate. According to Article 8 of this instrument: "[e]very member state of the League shall respect the form of government obtaining in the other states of the League, and shall recognize the form of government obtaining as one of the rights of those states, and shall pledge itself not to take action tending to change that form."

This approach has also been upheld by the International Court of Justice (ICJ) in the Western Sabara Advisory Opinion of 1975, ${ }^{3}$ as well as in the 1986 case, Nicaragua v. United States. ${ }^{4}$ In Western Sahara, the ICJ emphasized that: "[n]o rule of international law, in the view of the Court, requires the structure of a state to follow any particular pattern, as is evident from the diversity of the forms of state found in the world today," 5 while in Nicaragua, it pointed out the following:

A prohibited intervention must accordingly be one bearing on matters in which each State is permitted, by the principle of State sovereignty, to decide freely. One of these is the choice of a political, economic, social and cultural system, and the formulation of foreign policy .... A State's domestic policy falls within its exclusive jurisdiction, provided of course that it does not violate any obligation of international law ...

* Adjunct Lecturer, Hellenic Military Academy; Part-time Lecturer, National Police Academy; Expert-Rapporteur, Appeals Authority, Greek Asylum Service, and Researcher of the European Centre of Research and Training on Human Rights and Humanitarian Action, Panteion University.

Originally published online 29 Jan. 2015.

${ }^{1}$ Erika de Wet, From Free Town to Cairo via Kiev: The Unpredictable Road of Democratic Legitimacy in Governmental Recognition, 108 AJIL UnBOUND 201 (2015).

2 Pact of the League of Arab States, Mar. 22, 1945, 70 UNTS 237.

3 Western Sahara, Advisory Opinion, 1975 ICJ REP. 61 (Oct. 16).

${ }^{4}$ Military and Paramilitary Activities in and Against Nicaragua (Nicar. v. U.S.), 1986 ICJ ReP. 14 (June 27).

${ }^{5}$ Western Sahara, Advisory Opinion, para. 94, 1975 ICJ REP. 61 (Oct. 16).

ASIL and Vasiliki Saranti (C) 2015 
adherence by a State to any particular doctrine does not constitute a violation of customary international law; to hold otherwise would make nonsense of the fundamental principle of State sovereignty on which the whole of international law rests, and the freedom of choice of the political, social, economic and cultural system of a State.

However, after the end of the Cold War and the democratization processes initiated in many states, we witness the gradual emergence of the right to democracy as a rule of international law; as former UN Secretary-General Boutros Boutros-Ghali stressed in his Agenda for Democratization. ${ }^{6}$ The democratic legitimacy of a regime and respect for democratic principles are a prerequisite for active participation in the organs of an international organization; 7 Art. 25 African Charter on Democracy, Elections and Governance; ${ }^{8}$ Art. 45 ECOWAS Protocol on Democracy and Good Governance. ${ }^{9}$ As Professor de Wet notes in her contribution to this symposium, in at least two cases, (Haiti ${ }^{10}$ and Sierra Leone ${ }^{11}$ ), the UN Security Council has adopted coercive measures in order to ensure respect for the democratic order. This further demonstrates that democratic legitimacy is not a matter of exclusive domestic jurisdiction but that it concerns the international community as a whole, especially the neighboring states. The political crisis of November 2010 in Côte d'Ivoire $^{12}$ is a controversial case. UN Security Council Res. 1975 (2011) was explicit on the need for state institutions to yield to the authority vested by the people in President Alassane Ouattara, but the UN Operation in Côte d'Ivoire (UNOCI) was not authorized to use force in pursuance of that aim. To the contrary, UNOCI and the French forces were authorized by the Security Council to use force only in order to protect civilians.

I do not intend to expand further on the worldwide situation in general and in Africa in particular, since these have already been aptly developed by Professor de Wet in her contribution to this symposium. My intention in this piece is to demonstrate that democratic legitimacy as a criterion to recognize a government, although not universally accepted yet, has gained special momentum in the framework of the Organization of American States (OAS) to such an extent that one may validly contend that we are in the process of formation of a regional customary international law rule.

\section{Democratic Legitimacy in the Western Hemisphere}

In the Western hemisphere, particularly within the framework of the OAS, after the gradual collapse of the military regimes in Latin America, the concept of democracy emerged as a conditio sine qua non for the achievement of regional security and stability. The recognition of a regime and its participation in the OAS depends not only on the effective control it exercises over its territory, but also on its democratic/electoral legitimacy.

In 1985, the American states amended the OAS Charter, by virtue of the Cartagena Protocol, to include among its purposes the promotion and establishment of representative democracy. In 1991, through Resolution 1080 of the OAS General Assembly ${ }^{13}$ on "Representative Democracy," OAS member states agreed to

${ }^{6}$ GA Res. A/51/761 (Dec. 20, 1996).

${ }^{7}$ Treaty on European Union, art. VII, Feb. 7, 1992, 1992 O.J. 326.

8 African Union [AU], African Charter on Democracy, Elections and Governance, Jan. 30, 2007.

9 Economic Community of West African States [ECOWAS], Protocol on Democracy and Good Governance, ECOWAS Doc. A/SP1/12/01 (Dec. 21, 2001).

${ }^{10} \underline{\text { SC Res. } 940}$ (July 31, 1994).

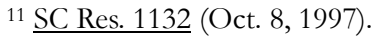

12 Post-Election Crisis, United Nations: United Nations Operation in Cote d’Ivoire [UNOCI].

13 Organization of American States [OAS], Representative Democracy, AG/Res. 1080 (XXI-O/91) (June 5, 1991). 
intervene collectively, by diplomatic means, in the domestic affairs of a member state in order to protect the democratic order. The Resolution 1080 mechanism was invoked in four cases: Haiti (1991-96), Peru (1992), Guatemala (1993), and Paraguay (1996). In those cases, the initiatives included the dispatch of fact-finding missions and other diplomatic delegations, but the OAS General Assembly never proceeded to the suspension of a member state.

In 1992, the Protocol of Washington, ${ }^{14}$ amending the OAS Charter, put forward for the first time the suspension of membership as a form of sanction where the democratic legitimacy of a state is disrupted, in particular "when the democratically constituted government of a state has been overthrown by force." This instrument entered into force in 1997, but the relevant article, Article 9, has never been invoked, and the instrument has not yet been ratified by all OAS member states.

\section{The Inter-American Democratic Charter}

The most important of these OAS developments was the approval of the Inter-American Democratic Charter ${ }^{15}$ (IADC) in 2001. The IADC is a soft law instrument, a resolution of the OAS General Assembly, approved unanimously by the Ministers of Foreign Affairs and Ambassadors of the OAS member states during a special session of the OAS General Assembly. The IADC does not amend the OAS Charter (although there is a question of whether it amends in particular Art. 9 of the OAS Charter, introduced by the Washington Protocol), nor does it have to be ratified in order to be implemented. Finally, states are not obliged to amend their national legislation in order to incorporate the provisions of the IADC.

Despite its soft law nature, it is generally accepted that the IADC is legally binding, since it is considered an authoritative interpretation of the OAS Charter, in keeping with Article 31(3)(a) of the Vienna Convention on the Law of Treaties. One may also find useful the position of the Inter-American Court of Human Rights on the legal effect of instruments that constitute authoritative interpretations of the OAS Charter, as articulated in the advisory opinion Interpretación de la Declaración Americana de los Derechos y Deberes del Hombre en el marco del artículo 64 de la Convención Americana sobre derechos humanos. ${ }^{16}$

Indeed, prior to the approval of the IADC, the delegates of the OAS member states sought advice from the Inter-American Juridical Committee, an OAS advisory body entrusted, inter alia, with the promotion of the progressive development and the codification of international law. According to its opinion on the legal nature of OAS General Assembly resolutions, the IADC having been approved by such a resolution: "the provisions of resolutions of this nature generally have as their purpose the interpretation of treaty provisions, the provision of evidence of the existence of customary norms .... The provisions of some resolutions of an organ of an international organization may have an obligatory effect." ${ }^{17}$ In the same document, the InterAmerican Juridical Committee stresses that: "it would be unnecessary to amend the OAS Charter, provided that the text of the Democratic Charter explicitly states that it is setting forth an interpretation of the OAS Charter and assuming of course that the IADC is adopted by consensus."18

\footnotetext{
14 OAS, Protocol of Amendments to the Charter of the OAS, "Protocol of Washington", A-56 (Dec. 14, 1992).

15 OAS, Inter-American Democratic Charter, Sept. 11, 2001.

${ }^{16}$ Interpretation of the American Declaration of the Rights and Duties of Man (Art. 64 American Convention on Human Rights), Advisory Opinion OC-10/89, Inter-Am. Ct. H.R. (ser. A) paras. 43, 45 (July 14, 1989). 2001).

17 OAS, Annual Report of the Inter-American Juridical Committee to the General Assembly, OAS/Ser.Q/VI.32CJI/doc.79/01 (Aug. 24 ,

$18 \underline{I d}$. at para. 40 .
} 
The resolution approving the IADC can be described as an "operational act" of the OAS General Assembly since it is "done in the course of the direct and substantive operations of the organization."19 The legal effects of such acts depend on the constitution of the organization. Since the OAS General Assembly is described as the "supreme organ of the OAS," competent to decide the general action of the organization (Article 54, OAS Charter), it goes without saying that its acts are binding upon member states. Of course the wording of each resolution adopted in each different case also has to be taken into account.

It is true, however, that legal impediments persist in the case where the OAS decides to suspend the government of a state that has not ratified the Washington Protocol. ${ }^{20}$ In fact there are academics who challenge the binding character of the IADC (see for instance, d'Aspremont, La licéite des coups d'état en droit international, in SFDI, L'état de droit en droit international).

The OAS has cited the IADC on various occasions: Haiti (2001-04), Venezuela (2002), Ecuador (2005), Belize (2005), Bolivia (2005), and Nicaragua (2005). In these cases, the OAS acted diplomatically even though in the case of Nicaragua the possibility of sanctions was left open. The first-and so far only-case of suspension of a member state from the OAS activities, by virtue of the IADC, was the case of Honduras in the summer of 2009. The Honduras case is made more important by the fact that it was not the classic "coup d'etat" but an unconstitutional alteration of the government, such as the one that took place in Ukraine.

\section{Is There a Regional Customary Rule on the Democratic Legitimacy of a State?}

Although the IADC constitutes an OAS General Assembly resolution and resolutions of this nature do not feature among the sources of law listed under Article 38 of the International Court of Justice Statute, there is no reason that prevents it from eventually crystallizing into customary law provided that both elements of the creation of customary rules are fulfilled.

In Nicaragua, ${ }^{21}$ the ICJ in deciding on the legal validity of the UN Declaration on Principles of International Law Concerning Friendly Relations and Cooperation among States, adopted by a UN General Assembly resolution, held that:

The effect of consent to the text of such resolutions cannot be understood as merely that of a 'reiteration or elucidation' of the treaty commitment undertaken in the Charter. To the contrary, it may be understood as an acceptance of the validity of the rule or set of rules declared by the resolution by themselves. ${ }^{22}$

The same holds for OAS General Assembly resolutions at the regional level. Indeed, the Court in the same case referred to a resolution of the OAS General Assembly to prove the opinio juris as to the customary rule on the prohibition of the use of force..$^{23}$

We should, however, take into account that the conditions needed to create a regional customary rule, as described by the ICJ, are particularly strict. In the famous Asylum case, ${ }^{24}$ regarding the political asylum offered to Haya de la Torre in the Colombian embassy in Lima, Colombia contended that, as the country granting asylum, it had the right to qualify the offence for the purpose of the said asylum, namely to classify him as a political refugee, relying, inter alia, on an alleged regional or local custom specific to Latin-American states. The ICJ did not accept that such a rule had been formulated. In particular it noted that:

19 C. F. Amerasinghe, Principles of the Institutional LaW Of INTERnATIONAL ORGANiZATIONS (2d ed. 2005).

20 Timothy D. Rudy, A Quick Look at the Inter-American Democratic Charter of the OAS: What is it and is it "Legal"?, 33 SYRACUSE J. INT'L L. \& COM. 237 (2005).

${ }^{21}$ Military and Paramilitary Activities in and Against Nicaragua (Nicar. v. U.S.), 1986 ICJ REP. 14 (June 27).

$22 \underline{I d}$. at para. 188.

${ }^{23} \underline{I d}$. at para. 192.

24 Asylum Case (Colom. v. Peru), 1950 ICJ ReP. 7 (Nov. 20). 
The Party which relies on a custom of this kind must prove that this custom is established in such a manner that it has become binding on the other Party. The Colombian Government must prove that the rule invoked by it is in accordance with a constant and uniform usage practiced by the States in question, and that this usage is the expression of a right appertaining to the State granting asylum and a duty incumbent on the territorial State.

The Court emphasized that: "[t]his follows from Article 38 of the Statute of the Court, which refers to international custom 'as evidence of a general practice accepted as law."'25

Colombia had relied particularly on the Montevideo Convention on Political Asylum (1933), contending that this Convention had merely codified principles that were already recognized by Latin American custom and that it was valid against Peru as a proof of customary law. However, the Court dismissed the argument, noting firstly that the Montevideo Convention had not been ratified by Peru and thus could not be invoked against that state and secondly that the said Convention was ratified by only a limited number of states. The Court also added that, despite the large number of particular cases in which diplomatic asylum was granted and respected, it was not shown that the alleged rule of unilateral and definitive qualification of the offence as political was exercised by the states granting asylum as a right appertaining to them and respected by the territorial states as a duty incumbent on them and not merely for reasons of political expediency. The Court concluded that it was not possible to discern any constant and uniform usage accepted as international law as there was so much uncertainty and contradiction, fluctuation and discrepancy in the exercise of diplomatic asylum, as well as in the official views expressed on various occasions; and inconsistency in the rapid succession of conventions, ratified by some states and rejected by others, and the practice influenced by considerations of political expediency.

If we follow the line of reasoning of the ICJ in the Asylum case, it would be very difficult to conclude that a regional customary rule regarding democratic legitimacy as a criterion of state recognition has emerged. The conventional instrument, namely the Protocol of Washington, has not been ratified by all OAS member states. Furthermore, Mexico has strongly opposed the idea of any kind of intervention in the internal affairs of the state once democratic legitimacy has been disrupted. According to its declaration ${ }^{26}$ at the time of the adoption of the Washington Protocol:

Mexico has reacted swiftly and firmly to disruptions of the constitutional order on numerous occasions in the past but remains convinced, nonetheless, that democracy is a process which comes from the sovereign will of the people, and cannot be imposed from outside. . . . it is unacceptable to give to regional organizations supra-national powers and instruments for intervening in the internal affairs of our States.

The Government of Mexico maintains that the preservation and strengthening of democracy in our region cannot be enhanced through isolation, suspension or exclusion ....

Mexico is opposed to the punitive character ascribed to the OAS.

It is true that the qualification of a regime alteration as an unconstitutional one, apart from being a matter clearly of national constitutional law, also involves a high risk of political and not legal evaluation. Nonetheless, the contradiction, uncertainty and inconsistency, crucial to the reasoning of the ICJ in the Asylum case, does not exist in the case of democratic legitimacy as a criterion for state recognition in Latin America. We have already underlined that the right to democracy emerged gradually in the Western hemisphere, from 1985 onwards. The IADC was only the culmination of the democratization process. To date, no state in the hemisphere has questioned the applicability and application of the IADC in specific circumstances. To the contrary, they have accepted as duly appropriate the multilateral intervention of the organization. The ap-

${ }^{25} \underline{\mathrm{I} d}$.

${ }^{26}$ OAS, Protocol of Amendments to the Charter of the OAS, "Protocol of Washington", A-56 (Dec. 14, 1992). 
proach was equally unanimous in the case of Honduras' suspension from participation until constitutional order was re-established. It is true that practice concerning the IADC is not abundant. However, should the opinio juris be followed by a consistent practice, in a few years this multilateral mechanism for defending democracy and the democratic legitimacy of a regime as a condition for recognition and participation in international institutions could become a local customary rule in the Americas. 